
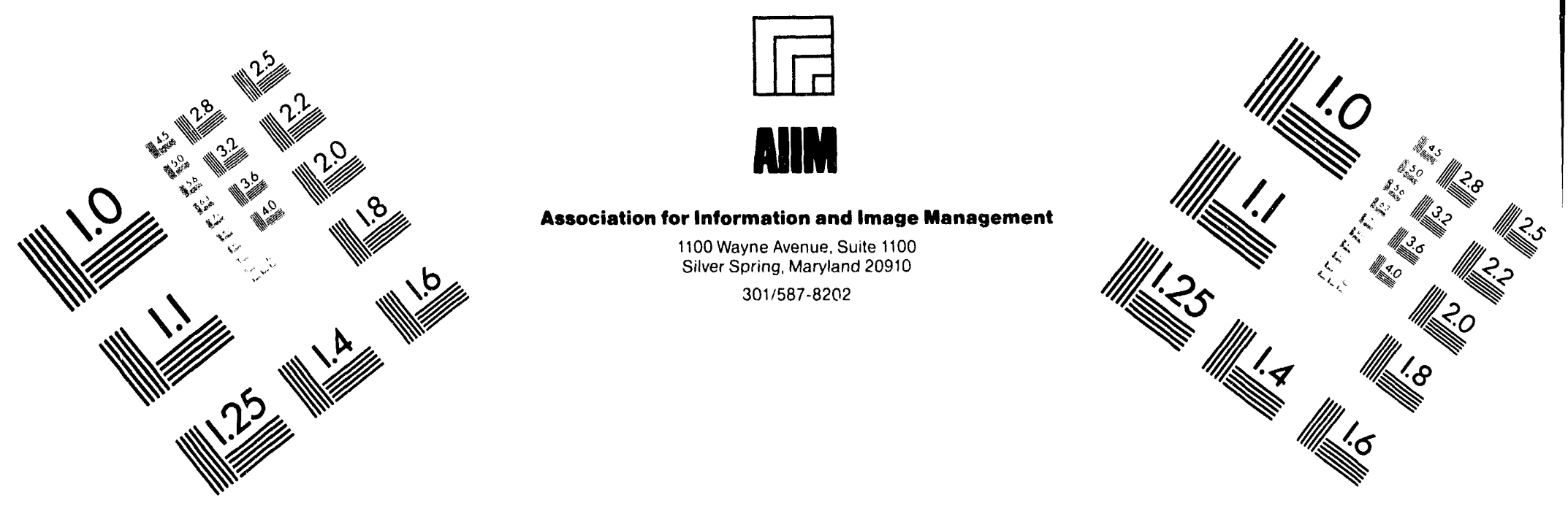

\title{
Centimeter
}

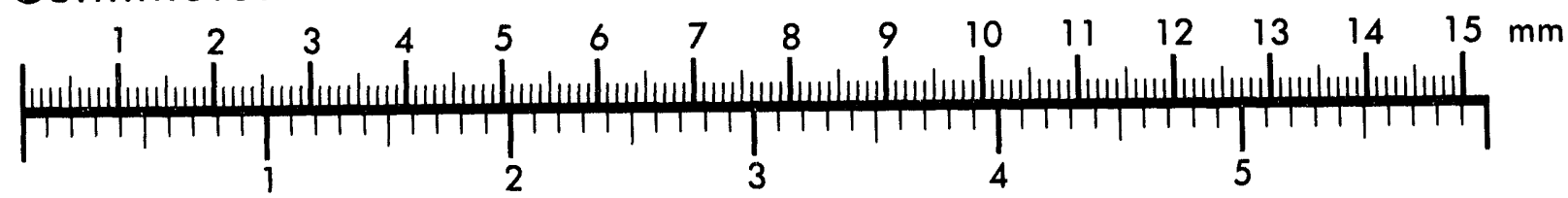
Inches
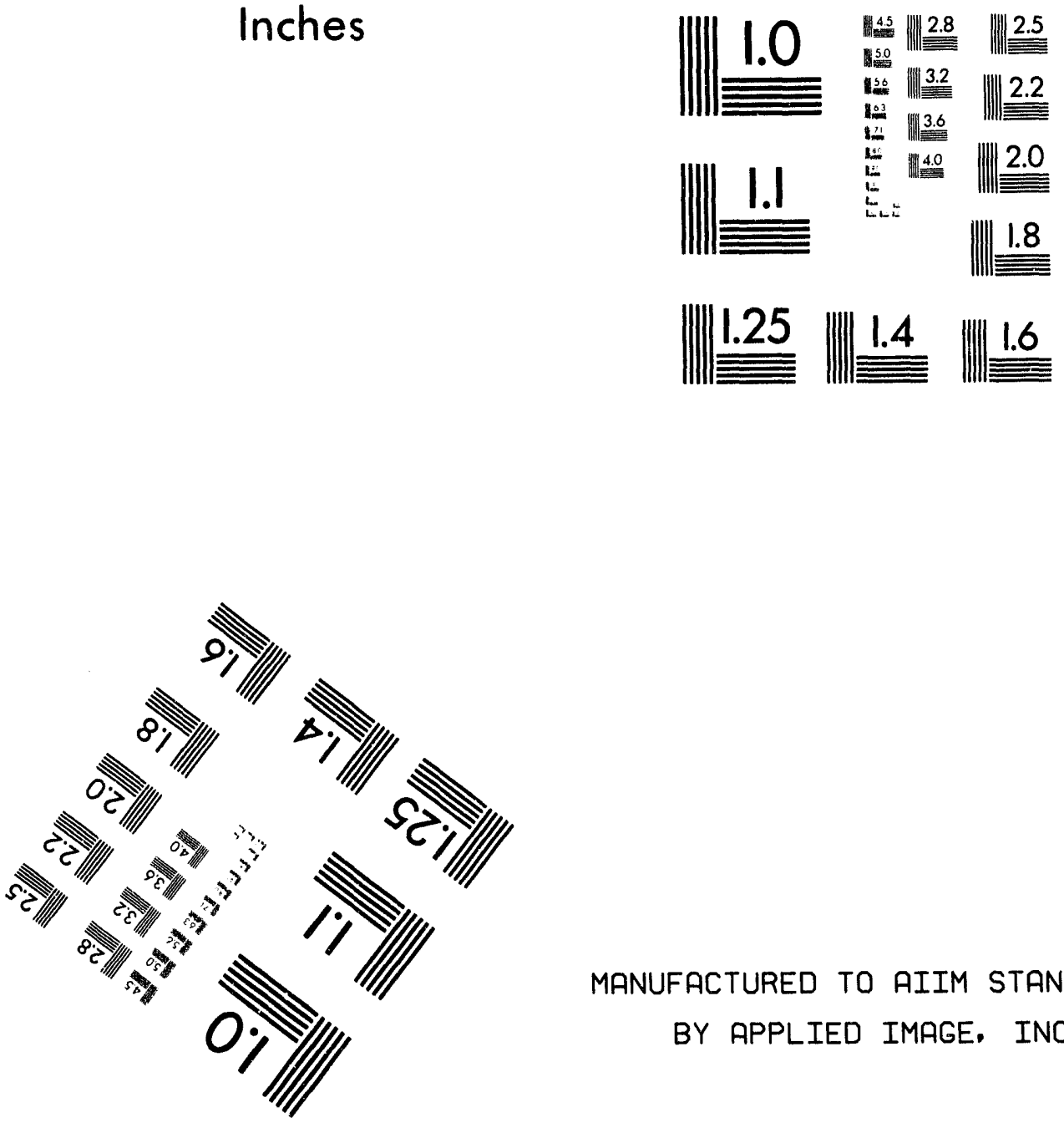

MANUFACTURED TO AIIM STANDARDS

BY APPLIED IMAGE, INC.

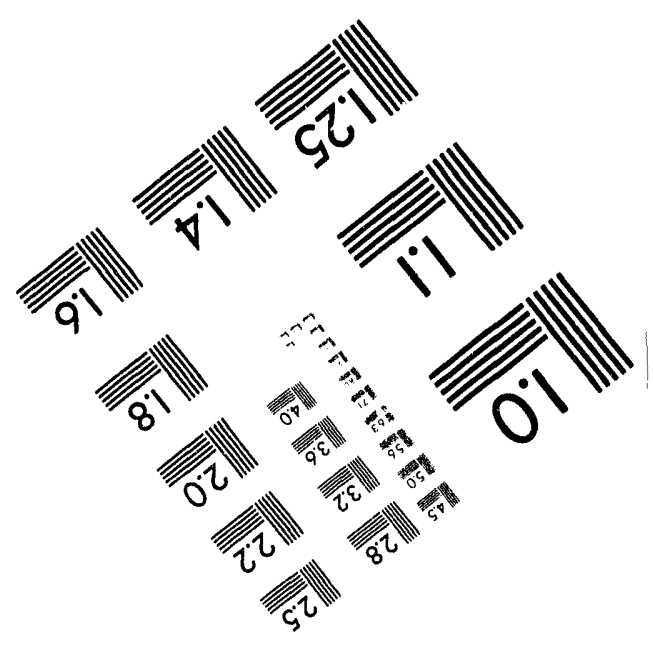



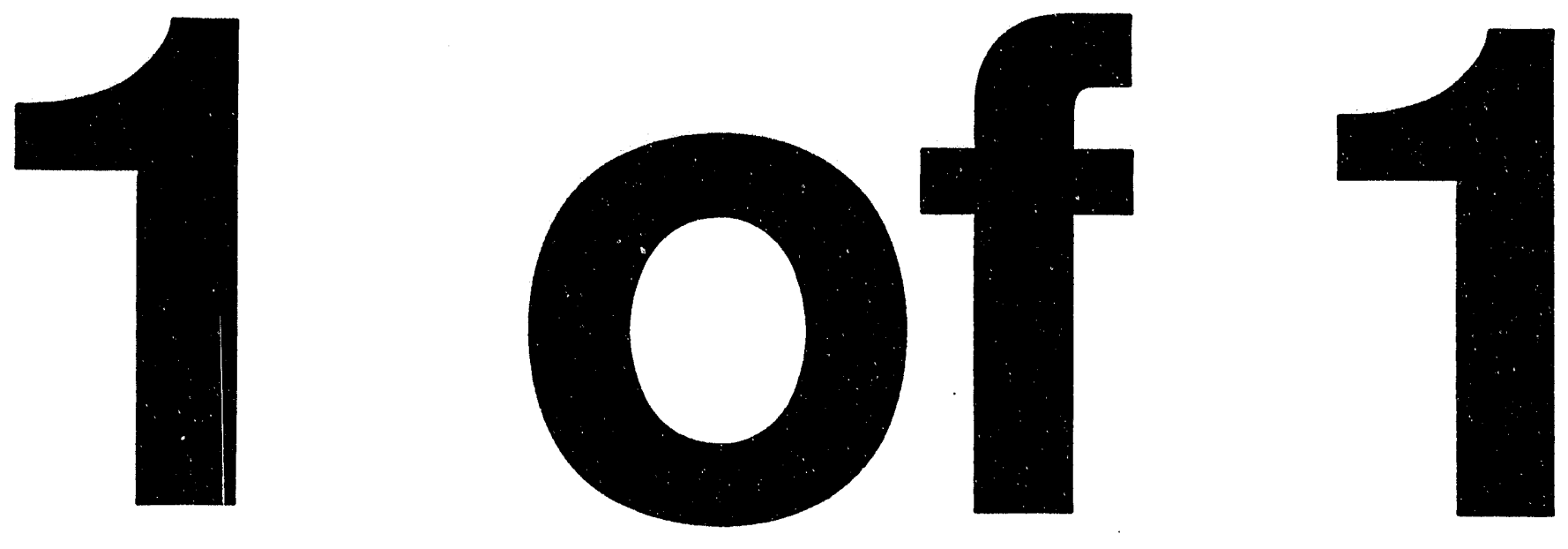


\section{7-S Nonradioactive Dangerous Waste Storage Facility Closure Plan}

ПECEIVES

FEB 221934

OSTI

Date Published

October 1992 
TRADEMARK DISCLAIMER

Reference herein to any specific commercial product, process, or service by trade name, trademark, manufacturer, or otherwise, does not necessarily constitute or imply its

endorsement, recommendation, or favoring by the United

States Government or any agency thereof or its contractors or subcontractors.

This report has been reproduced from the best available copy. Available in paper copy and microfiche.

Available to the U.S. Department of Energy

and its contractors from

Office of Scientific and Technical Information

P.0. Box 62

Oak Ridge, TN 37831

(615) $576-8401$

Available to the public from the U.S. Department of Commerce National Technical Information Service

5285 Port Royal Road

Springfield, VA 22161

(703) 487.4650

Printed in the Unitod States of America

DISCLM.5.CHP (8-91) 
RECORD OF REVISION

(1) Document Number

DOE/RL-88-37

(2) Title

2727-S Nonradioactive Dangerous Waste Storage Facility Closure Plan

CHANGE CONTROL RECORD

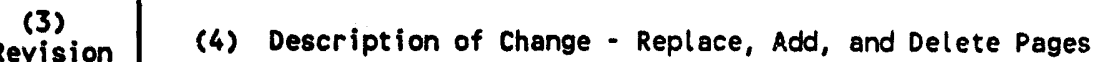

$3 A$ (7) Responses (noted with change bars) to

Ecology comments received $7 / 2 / 92,8 / 5 / 92$

and $9 / 4 / 92$; clarification of figures;

and, QAPP (APP G) change (noted with

change bars).

Page changes: Cover, Spine, Title Page, $v, 4-3,4-4,4-5,4-7,4-8,4-9,4-10$,

$4-11,4-13,5-1$, APP F-1, APP F-5, APP G-9

Authorized for Release

(5) Cog. Engr. (6) Cog. Mgr. Date

S. N. Luke F. A. Ruck 10/7/92

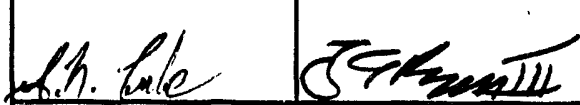




\section{CONTENTS}

1.0 INTRODUCTION . . . . .................. . . . .

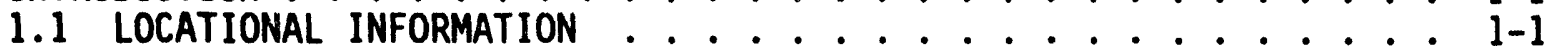

1.2 SECURITY . . . . . . . . . . . . . . . 1-3

1.3 FACILITY DESCRIPTION AND OPERATIONS $\cdots \cdots$

1.4 WASTES STORED AT THE $2727-S$ NRDWS FACILITY . . . . . . . . . 1-9

2.0 ClOSURE PERFORMANCE STANDARD . . . . . . . . . . . 2-1

3.0 ESTIMATE OF MAXIMUM INVENTORY OF WASTE . . . . . . . . . 3-1

4.0 CLOSURE ACTIVITIES . . . . . . . . . . . . . . . .

4.1 HOW THE 2727-S NRDWS FACILITY WILL BE CLOSED ....... 4-1

4.2 SAMPLING PLAN ..................... 4-2

4.2.1 2727-S Building Sampling . . . . . . . . 4-2

4.2.2 Concrete Sampling ............. 4-. 4

4.2.3 Soil Sampling ................. 4-. . .

4.3 DISPOSAL REQUIREMENTS .............. . . . . . . . . . .

4.3.1 The 2727-S Building Disposal . . . . . . . . . 4-12

4.4 EQUIPMENT DECONTAMINATION . . . . . . . . . . 4-12

4.5 RESTORATION ....................... 4-. . . . .

4.6 COST ESTIMATES $\ldots \ldots$

4.7 CERTIFICATION ................... . . . . . . . . .

5.0 CONTINGENCY PLAN . . . . . . . . . . . . . . 5-1

6.0 TRAINING REQUIREMENTS ................. . 6-1 6.1 PERSONNEL TRAINING ................... 6-1

7.0 ClOSURE PLAN SCHEdUle ................ . . . . .

8.0 REFERENCES ...................... . . . . . .

\section{APPENDICES}

DANGEROUS WASTE COMPLIANCE CHECKLIST/QUESTIONNAIRE

CHAPTER 173-303 WAC ........................ APP A-i

PHOTOGRAPHS .............................. APP B-i

SPILL REPORTS .......................... APP C-i

PART A PERMIT APPLICATION ....................... APP D-i

2727-S NRDWS FACILITY WASTE INVENTORY . . . . . . . . APP E-i

SAMPLING AND HANDLING PROCEDURES .............. APP F-i 
QUALITY ASSURANCE PROJECT PLAN . . . . . . . . . . . . APP G-i PERSONNEL TRAINING ...................... APP H-i CERTIFICATION STATEMENTS . . . . . . . . . . . . . . . . APP I-i

\section{FIGURES}

1 Regional Map .................... . . . . . . .

2 Vicinity Map 200 West Area . . . . . . . . . . . . . . . . . . 1-4

3 Site PIan 2727-S NRDWS Facility . . . . . . . . . . . . . . . 1-5

4 Waste Transportation Route to Hanford Site Boundary . . . . . . . . . 1-6

5 Concrete Pad and Building Plan . . . . . . . . . . . . . . 1-8

6 Soll Sampling Locations Within Building . . . . . . . . . . . 4-6

7 Soil Sampling Locations on Exterior Concrete Pad . . . . . . . . . 4-8

8 Specific Perimeter Sampling Site Plan, Soil . . . . . . . . . . 4-9

9 Background Soil Sampling Plan . . . . . . . . . . . . . 4-11

10 The 2727-S NRDWS Facility Closure Plan Schedule . . . . . . . . 7-2

\section{TABLES}

1 Offsite Treatment, Storage, and/or Disposal Facilities Receiving 2727-S Wastes.................... . 1-10

2 Sample Types and Number . . . . . . . . . . . . . . . . 4-4

3 Company-General Training Matrix . . . . . . . . . . . . . 6-2 
DOE/RL 88-37

Revision 3A

1 The DOE-RL and Westinghouse Hanford contend that through process knowledge and

2 historical records the 2727-S NRDWS Facility has received little or no contamination. Any sampling of the interior concrete pad will be performed in compliance with the receiving offsite RCRA landfill's waste analys is plan. Copies of any sample analytical report(s) prepared by the receiving offsite RCRA landfill will be promptly transferred to Westinghouse Hanford. Any sample information pertinent for recordkeeping purposes will be transmitted to Westinghouse Hanford from the receiving TSD facility within an acceptable time frame. Concrete coring will be performed on the interior concrete to obtain undisturbed soil samples (Section 4.2.3.1) underneath the pad. The coring procedure being used is documented in Appendix F.

4.2.2.2 Exterior Pad. The exterior pad consists of all portions of the exterior concrete pad not previously addressed in the description of the interior concrete pad. Waste containers were stored outside the 2727-S Building on the exterior pad when the building storage capacity was exceeded. The exterior pad will be disposed of in an offsite RCRA landfill.

Historical data indicates a limited potential for chemical contamination of the exterior concrete pad. However, instead of expending funds to perform an extensive sampling activity, clean closure will be achieved through handling and disposing of the 2727-S NRDWS Facility as a dangerous waste. The DOE-RL and Westinghouse Hanford contend that through process knowledge and historical records the 2727-S NRDWS Facility has received little or no contamination. Any sampling of the exterior concrete pad will be performed in compliance with the receiving offsite RCRA landfill's waste analys is plan. Copies of any sample analytical report(s) prepared by the receiving offsite RCRA landfill will be promptly transferred to Westinghouse Hanford. Any sample information pertinent for recordkeeping purposes will be transmitted to Westinghouse Hanford from the receiving offsite RCRA landfill within an acceptable time frame. Concrete coring will be performed on the exterior concrete to obtain undisturbed soil samples (Section 4.2.3.2) underneath the pad. The coring procedure being used is documented in Appendix F.

\subsubsection{Soil Sampling}

Soil sampling at the 2727-S NRDWS Facility will encompass the following specific areas.

- The soils along the perimeter fence.

These samples will be used to establish local background levels for establishing site cleanup criteria.

- The soils beneath the building.

- The soils beneath the exterior concrete pad.

- The soils outside the concrete pad perimeter.

- Areas of discolored soil. 
1 These samples will be used to verify that chemical contamination did not reach 2 the soil beneath the concrete (Table 2).

Table 2. Sample Types and Number.

\begin{tabular}{|c|c|c|}
\hline Sample media & Type of sample & Number of samples \\
\hline $\begin{array}{l}\text { Structural } \\
\text { material }\end{array}$ & None & \\
\hline $\begin{array}{l}\text { Interior } \\
\text { concrete pad }\end{array}$ & None & \\
\hline $\begin{array}{l}\text { Exterior } \\
\text { concrete pad }\end{array}$ & None" & \\
\hline $\begin{array}{l}\text { Soils beneath } \\
\text { interior pad }\end{array}$ & Verificationc & 6 - 3 per bay \\
\hline $\begin{array}{l}\text { Soils beneath } \\
\text { exterior pad }\end{array}$ & Verificationc & 10 - 2 per pad sample site \\
\hline Perimeter soils $s^{d}$ & Verificationc & 4 - 1 per each side of exterior pad \\
\hline $\begin{array}{l}\text { Soils beneath } \\
\text { stained areas }\end{array}$ & $\begin{array}{l}\text { Constituent } \\
\text { determination }\end{array}$ & 1 composite for both areas \\
\hline $\begin{array}{l}\text { Soils beneath } \\
\text { stained areas }\end{array}$ & Verification ${ }^{c}$ & 2 - 1 per each stained area \\
\hline $\begin{array}{l}\text { Soils along } \\
\text { perimeter fence }\end{array}$ & Background & 3 \\
\hline Total & & 26 total samples ${ }^{b}$ \\
\hline
\end{tabular}

24 Total

26 total samples ${ }^{b}$

Any samples taken from these areas will be at the request of the TSD facility selected to dispose of 2727-S NRDWS Facility.

This does not include field quality control samples. These samples will be taken for each matrix as required in the 2727-S NRDWS Facility Quality Assurance Project Plan (QAPP) (Appendix F).

Closure verification samples will be analyzed on an individual basis.

Includes field screening of each sample by $X$-ray fluorescence.

4.2.3.1 Solls Beneath the Building. The top 6 in. of soil immediately beneath the 2727-S Building pad will be removed and disposed of along with the concrete section immediately above it. The soils beneath the top 6 in., which are not scheduled for removal and disposal, will be sampled to verify the absence of soil contamination below the planned depth of disposal. This will 
1 require access to the soils through the concrete pad. Closure verification 2 sampling will take place before any removal and disturbance of soils at the 3 site.

The 2727-s Building was constructed with the floor divided into two bays. It has been agreed that the soil beneath each bay will be sampled. The selection of sampling points has been made with input from Ecology and can be seen in Figure 6 . The sample location in the west bay area is located at the junction of cracks in the floor. This is a likely pathway for any contamination to reach the support soils beneath the 2727-s Building. The sampling point in the east bay of the 2727-S NRDWS Facility is located on a stain in the northerly area of the concrete. This staining is attributed to this point being the lowest in the east bay; therefore, liquids on the floor may have collected at this point. The stain appears to be algae growth from rainwater periodically pooling in the area since the 2727-S Building use ceased.

The procedure outlined in Appendix $F$ will be followed for the removal of concrete cores to obtain access to the soil. After removal of the concrete cores, soil samples will be taken. Soil sampling will follow the guidelines set forth in EII 5.2 "Soil and Sediment Sampling" of WHC-CM-7-7, Environmental Investigations and Site Characterization Manual. The sample collection method used to collect samples will be either the use of a thin-walled ('Shelby') tube, a hand auger or scoop, spade, or shovel sampling technique. These methods are discussed in Appendices $C$ and $E$, respectively, of WHC-CM-7-7. The specific method chosen to take samples will depend on field conditions at the time of sample collection.

Given the extent and nature of storage activities at the 2727-S NRDWS Facility, it is unlikely that any soil with evidence of chemical constituents above background levels will be present. In the event that any constituents above background levels are determined to be present in these closure verification samples, the next $6 \mathrm{in}$. of soil would be removed and disposed of in an offsite RCRA landfill. If any soil is removed because of chemical contamination (other than the topmost 6-in. layer scheduled for removal with the interior pad), a buffer zone will be implemented. The buffer zone will consist of removing the adjoining soil to a circular distance of $5 \mathrm{ft}$ and a depth of 4 in. past the last known point or area of soil contamination. Closure verification sampling will be performed by taking 4 samples located in a $5 \mathrm{ft}$ radius around the remediated area (including the buffer zone), and one sample located in the center of the same area.

4.2.3.2 Soils Beneath Exterior Pad. The soils beneath the exterior pad at the 2727-S NRDWS Facility will be sampled in the same manner as the soils beneath the building pad. The difference is in the depths from which soil will be sampled. Samples beneath the exterior pad will be taken from a depth of 0-6 in., and from 18-24 in. These soil samples will be used as closure verification samples for that particular section of the concrete pad. However, unlike the soil removal action under the interior concrete pad, the 
DOE/RL 88-37

Revision 3
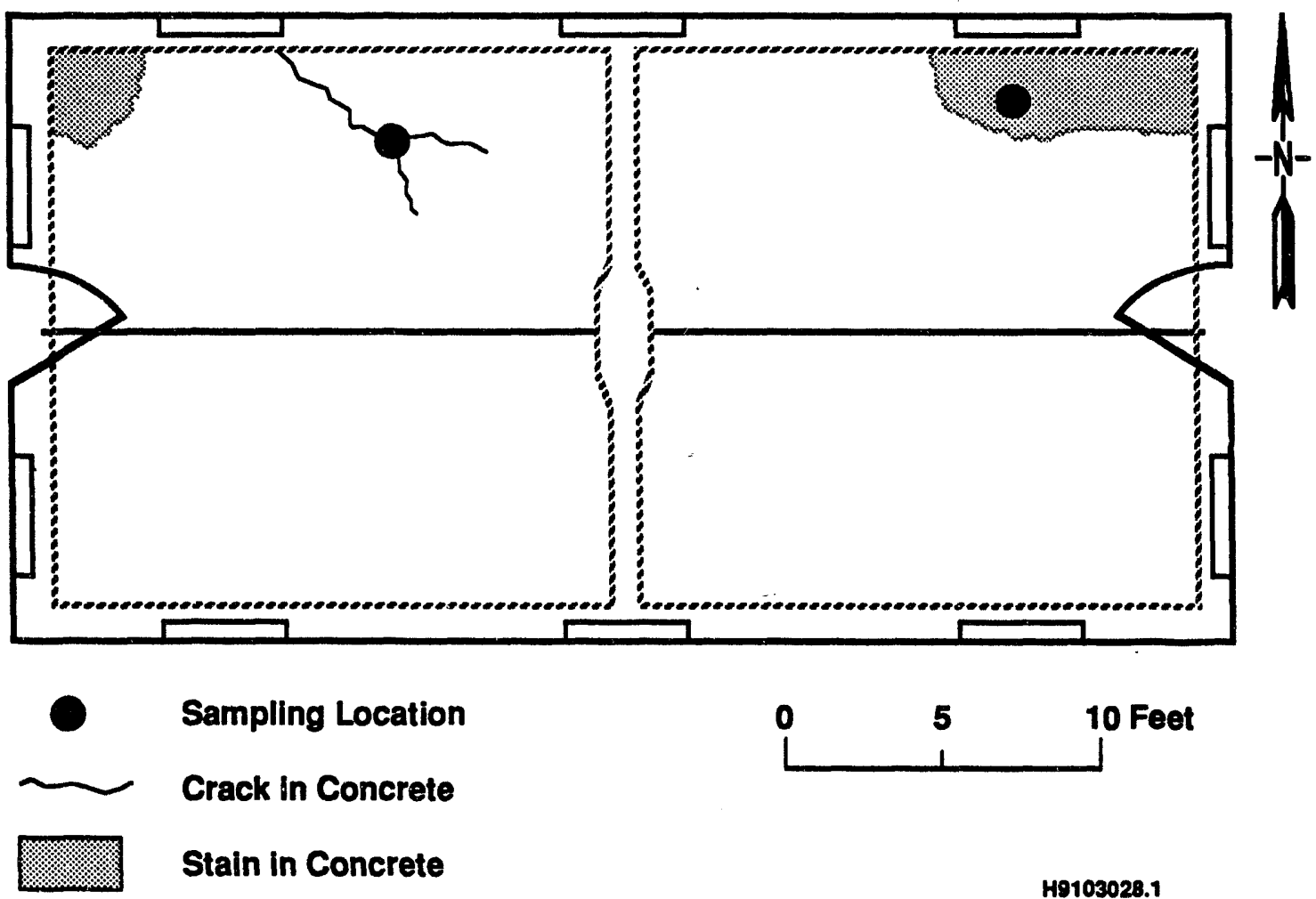

H9103028.1

Figure 6. Soil Sampling Locations Within Building. 
topmost 6 in. of soil under the exterior pad will not be removed unless evidence of chemical contamination is present. The selection of sampling points has been made with input from of Ecology and can be seen in Figure 7 .

The procedures outlined in Appendix $F$ will be followed for the removal of concrete cores to obtain access to the soil. After removal of the concrete cores, soil samples will be taken. Soil sampling will follow the quidelines set forth in EII 5.2 "Soil and Sediment Sampling" of WHC-CM-7-7, Environmental Investigations and Site Characterization Manual. The sample collection method used to collect samples will be either a thin-walled ('Shelby') tube, a hand auger or scoop, spade, or shovel sampling technique. These methods are discussed in Appendices $C$ and $E$, respectively, of WHC-CM-7-7. The specific method chosen to take samples will depend on field conditions at the time of sample collection.

Given the extent and nature of storage activities at the 2727-S NRDWS Facility, it is unlikely that any soil with evidence of chemical constituents above background levels will be present. If any constituents above background levels are determined to be present in the closure verification samples, the next 6 in. of soil would be removed and disposed of in an offsite RCRA landfill.

If any soil is removed because of chemical contamination, a buffer zone will be implemented. The buffer zone will consist of removing the adjoining soil to a circular distance of $5 \mathrm{ft}$ and a depth of 4 in. past the last known point or area of soil contamination. Closure verification sampling will be performed by taking 4 samples located in a $5 \mathrm{ft}$ radius around the remediated area (including the buffer zone), and one sample located in the center of the same area.

4.2.3.3 Perimeter Soils. Soil surrounding the exterior pad will be sampled to verify that waste handling activities did not affect it. There will be four samples taken from the perimeter soils. The selection of sampling points has been made under the guidance of Ecology. Samples will be taken to a depth of 6 in.

The soil sample location for each side of the pad is shown in Figure 8 . Each sample location was selected based on the assumption that this would be the side most likely to encounter detectable levels of chemical constituents in the soil. The north and west sample locations are in surface depressions. The east sample location is at the area where the transport trucks entered and left the site. The south sample location is located approximately south of the southwest corner of the 2727-S Building.

Two areas of discolored soil, soil stains No. 1 and No. 2, shown in Figure 8, will be sampled, analyzed, and removed as a separate and distinct removal action. Soil stain No. 1 is located in perimeter soils along the south edge of the exterior pad. Soil stain No. 2 is located in a soil-filled culvert that surfaces within the exterior pad. Soil stain No. 2 will be removed laterally to the culvert walls and to a depth of 4 in. deeper than the last visible area of contamination. Soil stain No. 1 will be completely removed to a depth of $4 \mathrm{in}$. deeper than the last visible area of contamination 
6.8208016H

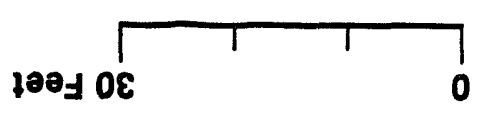

(ju!̣or uolsuedx引) wees

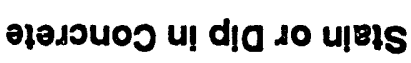

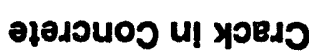

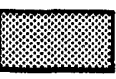

uolfeso7 bu!ndues

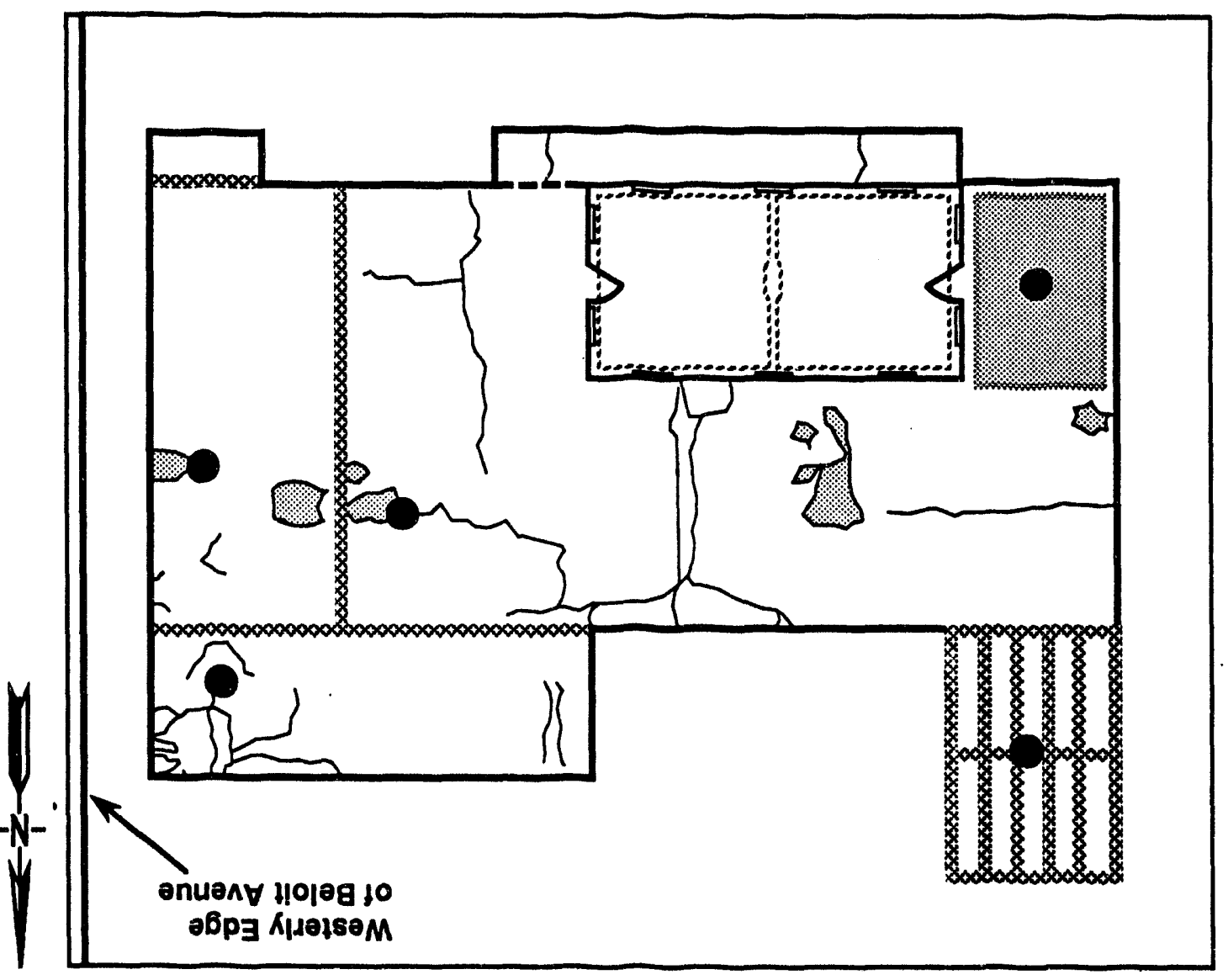


DOE/RL 88-37

Revision $3 A$

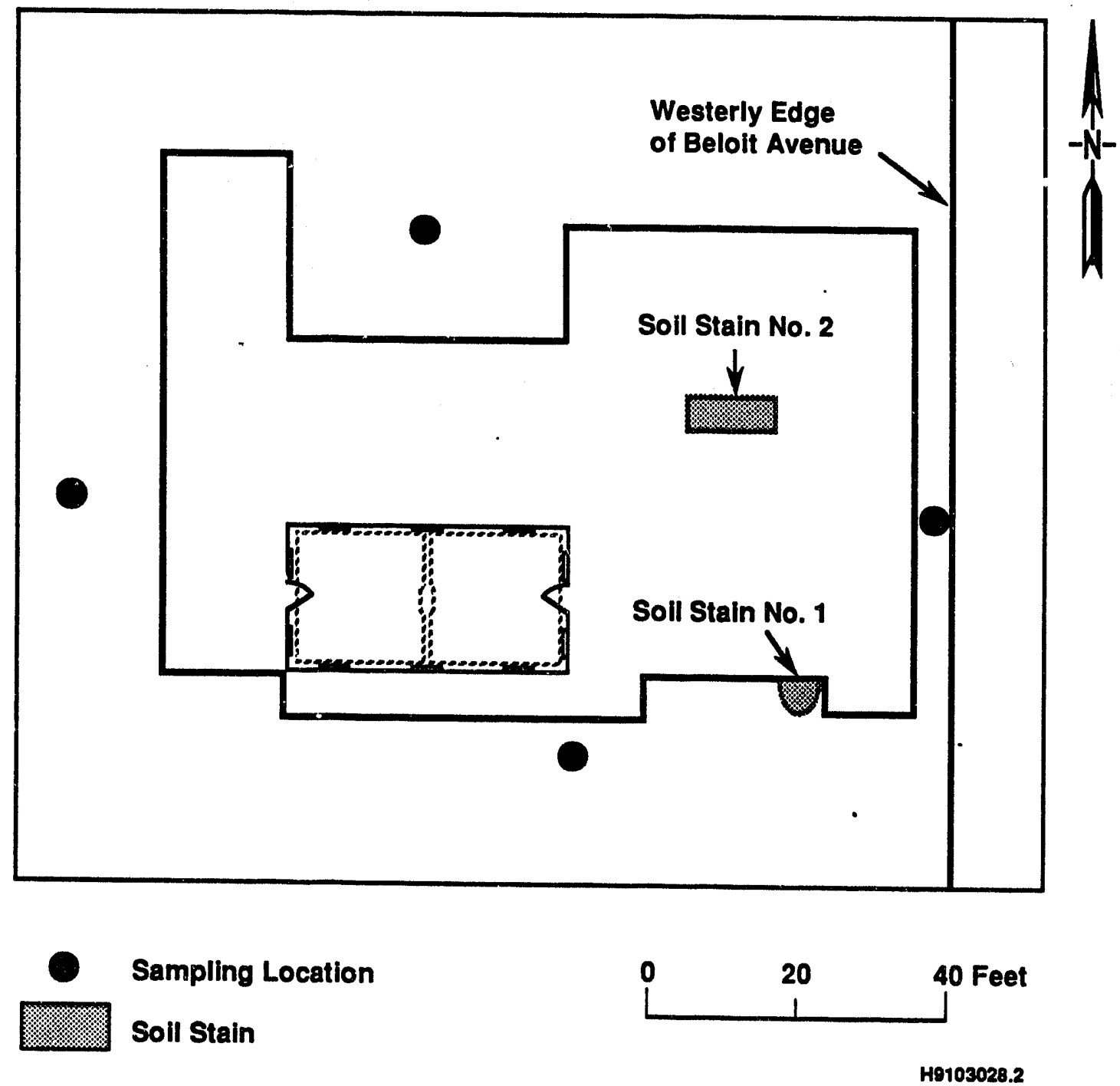

Figure 8. Specific Perimeter Sampling Site Plan, Soil. 
and will include a 5-in. lateral buffer. Each stained soil removal area will have one verification sample taken, which may be taken prior to the stained soil removal. If analysis indicates a waste code comparable to the 2727-S NRDWS Facility, removed soil may al so be shipped to the offsite RCRA landfill. If found to be a dangerous waste, the area will be subject to the same soil removal criteria as other portions of the 2727-S NRDWS Facility, except that once contaminated soil is removed, only one verification sample, obtained from the center of this area, will be required.

If any soil is removed because of chemical contamination in the remaining four perimeter locations, a buffer zone will be implemented. The buffer zone will consist of removing the adjoining soil to a circular distance of $5 \mathrm{ft}$ and a depth of 4 in. past the last known point or area of soil contamination. Closure verification sampling will be performed by taking 4 samples located in a $5 \mathrm{ft}$ radius around the remediated area (including the buffer zone), and one sample located in the center of the same area.

Soil sampling will follow the guidelines set forth in EII 5.2 "Soil and Sediment Sampling" of WHC-CM-7-7, Environmental Investigations and site Characterization Manual. The sample collection method used to collect samples will be either the use of a thin-walled ('Sheiby') tube, a hand auger or scoop, spade, or shovel sampling technique. These methods are discussed in Appendices $C$ and $E$, respectively, of $W H C-C M-7-7$. The specific method chosen to take samples will depend on field conditions at the time of sample collection.

Closure verification sampling will then be done at five locations. Four of the closure verification samples will be located within $5 \mathrm{ft}$ of the perimeter of the remediated area: one each to the north, south, east, and west. The fifth closure verification sample will be located in the center of the remediated area. Any closure verification sample with chemical constituents present above background levels will have the soil removed and disposed of in the same manner discussed previously. This process would continue as necessary until verification of adequate soil removal is achieved.

4.2.3.4 Soil Background. The soil located along the perimeter fence of the 2727-S NRDWS Facility will be sampled to determine background level of chemical constituents. There will be three samples taken from within the perimeter fence. The amount and selection of sampling points has been made with input from Ecology and can be seen in Figure 9. One sample will be obtained from each portion of the fence not bordered by Beloit Avenue. Hence, the northern, western, and southern fence line will have one sampling location each. The exact location will be chosen by the responsible Westinghouse Hanford field sampling personnel.

Soil sampling will follow the guidelines set forth in EII 5.2 "Soil and Sediment Sampling" of WHC-CM-7-7, Environmental Investigations and site Characterization Manual. The sample collection method used to collect samples will be either a thin-walled ('Shelby') tube, a hand auger or scoop, spade, or shovel sampling technique. These methods are discussed in Appendices $C$ and $E$, respectively, of WHC-CM-7-7. The specific method chosen to take samples will depend on field conditions at the time of sample collection. 


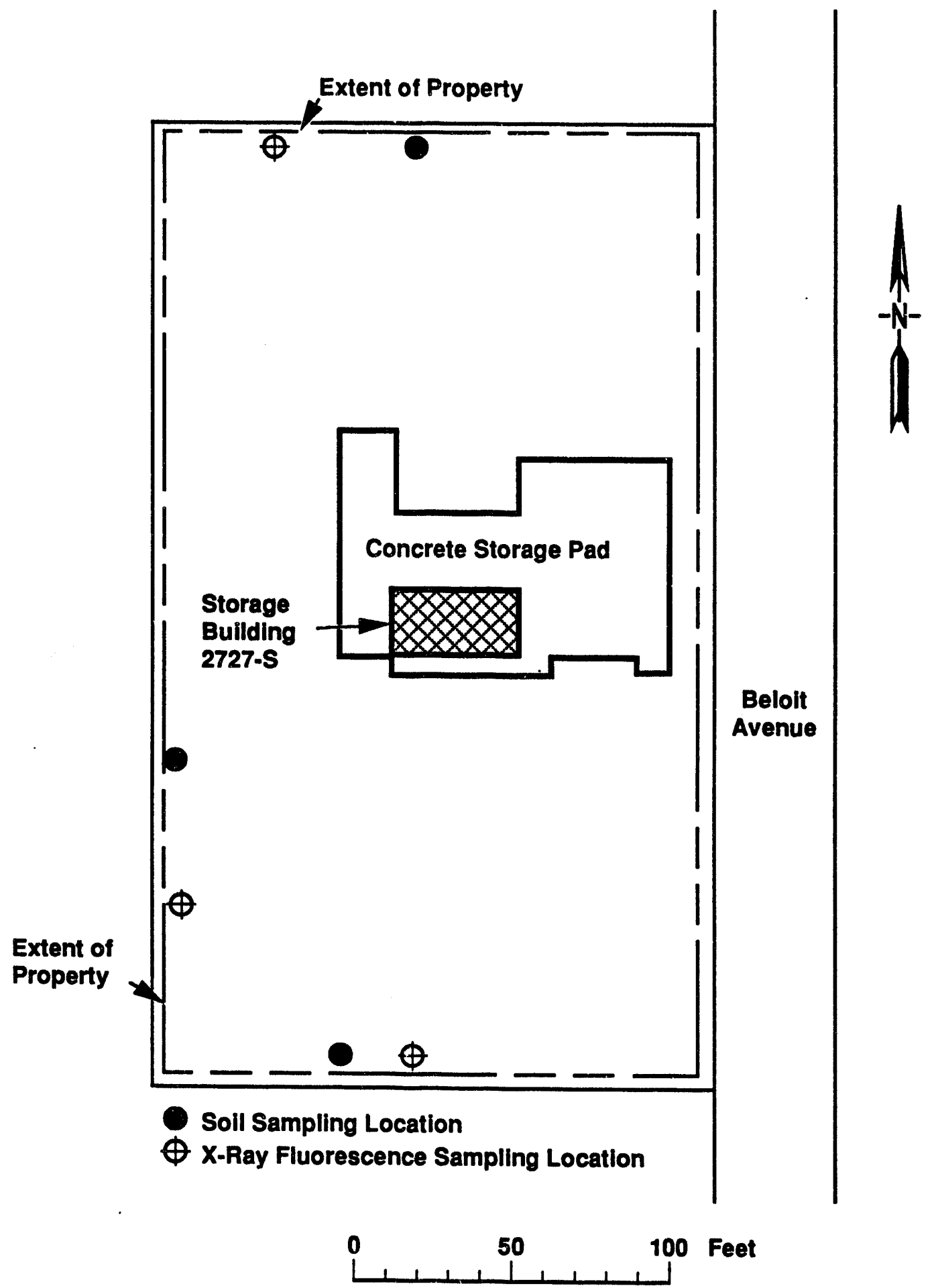

H9110024.1

Figure 9. Background Soil Sampling Plan.

*NOTE: All sampling locations are approximations. 
An $X$-ray fluorescence device will be used as a field screening technique onsite (Appendix F). To calibrate the $X$-ray fluorescence device for local background constituents, an additional three sampling locations along the perimeter fence is required. Exact locations will be chosen at the discretion of the personnel responsible for calibration of the device; however, they will be in the proximity of the three original perimeter fence sample locations.

\subsection{DISPOSAL REQUIREMENTS}

\subsubsection{The 2727-s Building Disposal}

The 2727-S Building is a 20 by $40 \mathrm{ft}$ metal structure with interior wallboard, insulation, and electrical wiring.

The 2727-S Building has a personnel door at each end and windows on all four walls. The structure is lined internally with insulation and walliboard. Trained personnel visually inspected the building and no evidence of asbestos was indicated. This conclusion was supported by process knowledge of the personnel responsible for building operations. The wallboard covers only the upper half of the walls, while the insulation lines both upper and lower walls. Because of the possible presence of polychlorinated biphenyls (PCBs), any fluorescent light ballasts present in the building will be removed before disposal of the building in an offsite RCRA landfill. Any fluorescent light ballasts from the 2727-S Building will be placed in an onsite PCB warehouse. Discarded fluorescent light tubes are considered a dangerous waste because of the presence of phosphorus. Discarded fluorescent light tubes from the 2727-S Building will be removed and managed in accordance with Westinghouse Hanford onsite treatment procedures.

\subsection{EQUIPMENT DECONTAMIMATION}

Care will be taken in field sampling to ensure that there is no cross contamination of samples by sampling equipment. To prevent this source of contamination, freshly cleaned and decontaminated sampling tools will be used. When equipment must be reused in the field, it will be cleaned as thoroughly as practical. For this purpose, stringent laboratory cleaning procedures have been modified for field conditions as documented in WHC-CM-7-7, Environmental Investigation Instruction (EII) 5.5, "Decontamination of Equipment for RCRA/CERCLA Sampling."

\subsection{RESTORATION}

Upon removal of waste residues and contaminated structures or soil, including waste generated during closure, the site may require some degree of reclamation. This may be justified to control dust, erosion, and surface water run-off and to promote postclosure usage. Site restoration will include backfilling disturbed soil areas with noncontaminated native soils, compaction, grading; and revegetation. 
DOE/RL $88-37$

Revision $3 A$

\subsection{COST ESTIMATES}

It is DOE-RL's understanding that federal facilities are not required to comply with WAC 173-303-620 (1991a). However, projections of anticipated costs of closure will be provided annually during closure activities (starting October 1992).

\subsection{CERTIFICATION}

Within 60 days of completion of closure of the 2727-S NRDWS Facility, certifications will be submitted. Suggested certification statements are contained in Appendix I. The independent registered professional engineer who will be monitoring closure will visit the site at least at the commencement and end of each activity described in the closure plan (e.g., soil sampling, building removal, soil excavation, etc.). The professional engineer will review all records, notes, analyses, files, manifests, etc. relating to the closure activities. After the final professional engineer closure certification has been executed, a responsible DOE official will certify that the facility has been closed in accordance with the closure plan. The responsible government official(s) is identified in Appendix I. 
DOE/RL 88-37

Revision 3

1
2
3
4
5

This page intentionally left blank. 


\subsection{CONTINGENCY PLAN}

A health and safety $\mathrm{plan}$ (HASP) is required for all hazardous waste sampling sites. This plan is intended to specify information pertinent to field assignments and to be a guide in unusual situations or emergencies. A site-specific version of the general RCRA/CERCLA investigation health and safety plan will be developed by Westinghouse Hanford to be used for RCRA sampling at the 2727-S NRDWS Facility. This plan will be developed and completed before initiation of RCRA sampling activities in accordance with EII 2.1, "Preparation of Health and Safety Plans." The finalized version of this plan will be forwarded to Ecology. 
DOE/RL 88-37

Revision 3

This page intentionally left blank. 
DOE/RL 88-37

Revision $3 A$

\author{
APPENDIX F \\ SAMPLING AND HANDLING PROCEDURES
}

\title{
1.0 INTRODUCTION
}

This appendix out lines (or describes where necessary) the procedures that will be followed in the collection and handling of samples at the 2727-S Nonradioactive Dangerous Waste Site (NRDWS) Facility. For the most part, these procedures are contained in WHC-CM-7-7, Environmental Investigations and Site Characterization Manual (WHC 1989) and referenced where applicable in the sampling plan (Chapter 4.0). Table F-1 identifies those procedures that will be followed for sample collection and handling during the 2727-S NRDWS Facility field activities. The two following techniques are addressed because a written procedure does not yet exist in WHC-CM-7-7.

Concrete Coring--Section 2.0 out 1 ines the basic procedures for extracting concrete cores for the purpose of obtaining soll samples for Resource Conservation and Recovery Act of 1976 (RCRA) investigations.

$X$-Ray Fluorescence (XRF)--The procedure for field screening techniques, to be used at hazardous waste sites on the Hanford Site, is currently in development. Section 3.0 outlines the analysis plan for 2727-S NRDWS soil sampling that has been prepared using the draft form of Hanford Site XRF procedures. A finalized version of a procedure documenting the use of the $x$-Met is under discussion with Ecology and will remain outside the scope of this closure plan.

\subsection{CORE DRILL SAMPLING}

\subsection{PURPOSE}

This procedure describes the methods and equipment required to core drill through concrete floor structures for the purpose of obtaining RCRA samples for site characterization at the 2727-S. NRDWS Facility. These samples will consist of concrete and/or soils.

Access to the underlying soils will be obtained by coring through the concrete floors. The cores will be drilled using concrete coring equipment. From each concrete core hole access, samples of the underlying soils will be

"X-Met is a trademark of Outokumpu. 
Table F-1. Investigative Procedures for 2727-S Nonradioactive Dangerous Waste Site Facility Sampling.

Procedure Title"

EII 1.1 Hazardous Waste Site Entry Requirements 
DOE/RL 88-37

Revision $3 A$

\subsection{X-RAY FLUORESCENCE SAMPLING}

\subsection{INTRODUCTION}

Field screening for heavy metals using a portable XRF analyzer provides a means to determine levels of contamination by heavy metals in the field. This document reports in draft form the technical basis and site-specific procedures to be used in field screening of soil samples from the 2727-S NRDWS Facility for detection of elemental contaminants, which may be present. This plan will discuss generalized site- and task-specific requirements and procedures for sample collection, data handling, and data evaluation. The final versions of specific procedures are under discussion with Ecology and will remain outside the scope of this closure plan.

\subsection{BACKEROUND INFORMATION}

Although process knowledge indicates a limited potential for chemical contamination in the 2727-S Facility, soils beneath the concrete pad are to be sampled before demolition to verify that no contamination exists below the planned depth of disposal. After demolition, if further remediation is necessary due to the presence of metals, XRF will be used as a field screening technique. This will assist in determining the extent of contamination.

\subsection{NALYTICAL REQUIREMENTS}

The $X$-Met- 880 is to be used to detect the presence of inorganic contaminants in soil and concrete. Qualitative or semiquantitative data is to be provided on a quick turnaround basis, subject to confirmation by validated laboratory tests. The basic goal of field screening is to quickly identify elevated levels of elemental contaminants in soils.

Most elements are present in soils at some concentration. Table F-2 indicates typical ranges of concentration for various elements amenable to analysis by XRF. Because most elements of interest are likely to be present as part of the natural background, the basic function of XRF analys is is to identify situations when a particular element is present in concentrations significantly above typical background levels. However, this must be based on background levels specific to the soil under analysis.

Factors that affect the ability of a field-portable XRF unit to detect and quantify a specific element include matrix scattering and absorption, secondary excitation, and peak overlaps. Also, because the $X$-Met uses isotopic sources with fixed energy levels to irradiate the sample, the relative efficiency by which a given element can be excited will depend on the relationship between the absorption edge and the source energy lines.

The X-Met determines elemental concentrations by means of "models" in which measurements of total count rates are made in a maximum of ten "windows" associated with specific elements. Peak overlap effects are accounted for by 
28

29

30

31

32

33

Table F-2. Typical Concentration of Various Elements in Soils.

\begin{tabular}{|c|c|}
\hline Element & Common range for soils (ppm) \\
\hline Arsenic & $1-50$ \\
\hline Barium & $100-3,000$ \\
\hline Bromine & $1-10$ \\
\hline Cadmium & $0.01-0.70$ \\
\hline Cesium & $0.3-25$ \\
\hline Chromium & $1-1,000$ \\
\hline Cobalt & $1-40$ \\
\hline Copper & $2-100$ \\
\hline Gallium & $5-70$ \\
\hline Germanium & $1-50$ \\
\hline Iodine & $0.1-40$ \\
\hline Iron & $7,000-550,000$ \\
\hline Lanthanum & $1-5,000$ \\
\hline Lead & $2-200$ \\
\hline Mercury & $0.01-0.3$ \\
\hline Manganese & $20-3,000$ \\
\hline Molybdenum & $0.2-5$ \\
\hline Nickel & $5-500$ \\
\hline Rubidium & $50-500$ \\
\hline Selenium & $0.1-2$ \\
\hline Silver & $0.01-5$ \\
\hline Strontium & $50-1,000$ \\
\hline Tin & $2-200$ \\
\hline Titanium & $1,000-10,000$ \\
\hline Vanadium & $20-500$ \\
\hline Yttrium & $25-250$ \\
\hline Zinc & $10-300$ \\
\hline Zirconium & $60-2,000$ \\
\hline
\end{tabular}

-Source: Lindsay, W. (1979) Chemical Equilibrium in

Solls; John Wiley \& Sons, New York, 1979. 


\subsection{VALIDATION}

Validation of the completed data package shall be performed by Westinghouse Hanford OSM personnel. The following validation requirements shall be defined within approved OSM data validation procedures at a minimum of Level B as outlined in Westinghouse Hanford's Sample Management and Administration WHC-CM-5-3, (WHC 1990b).

- Sample holding times

- Accuracy (i.e., spikes, control standards, etc.)

- Precision (i.e., duplicates, splits, etc.)

- Blanks.

\subsection{FINAL REVIEY AND RECORDS MANAGEMENT CONSIDERATIONS}

All validation reports and supporting analytical data packages shall be subjected to a final technical review by a qualified reviewer at the direction of the Technical Lead before submittal to regulatory agencies or inclusion in reports or technical memoranda. All validation reports, data packages, and review comments shall be retained as permanent project quality records in compliance with EII 1.6, "Records Management" (WHC 1989a) and QA 17.0, "Quality Assurance Records" (WHC 1989b). 


\subsection{INTERNAL QUALITY CONTROL}

All analytical samples shall be subject to in-process quality control measures in both the field and laboratory. Unless superseded by specific directions provided in the sampling plan, the following minimum field quality control requirements apply. The following requirements are adapted from Test Methods for Evaluating Solid Waste (SW-846) (EPA 1986), as modified by the proposed rule changes included in the Federal Register, Volume 54, No. 13 (EPA 1989).

- Duplicate samples--For each shift of sampling activity under an individual sampling subtask, a minimum of 5 percent of the total collected samples shall be duplicated. Field duplicate samples are samples retrieved from the same sampling location using the same equipment and sampling technique, but analyzed independently. Laboratory duplicate samples are samples taken successively from the same bulb. Duplicate samples are generally used to verify the repeatability or reproduceability of the analytical data.

- Split samples--At the Technical Lead's direction, field or field duplicate samples may be split in the field and sent to an alternative laboratory as a performance audit or the primary 1aboratory. Frequency shall meet the minimum requirements identified in the bullets below.

- Field/Equipment Blanks--A water blank consists of pure deionized, distilled water whose chemical composition is known, drawn through decontaminated sampling equipment and taken as a sample. Blanks are used to verify the adequacy of sampling equipment decontamination procedures and are used to check for possible contamination originating with the sampling environment. Blanks will be run before the initiation of sampling each day or if blank contamination is suspected or detected.

The internal quality control checks performed by analytical laboratories' laboratory analyses shall meet the following minimum requirements:

- Matrix spiked (MS) and matrix spiked duplicate (MSD) samples--Matrix spiked and matrix spiked duplicate samples require the addition of a known quantity of a representative analyte of interest to the sample as a measure of recovery percentage. The spike shall be made in a replicate of a field sample. Spike compound selection, quantities, and concentrations shall be described in the laboratories analytical procedures. Minimum QC requirements should be an analysis of either a (1) MS/MSD analysis, of (2) matrix spike and duplicate sample analysis at a frequency of once/batch or once every 20 samples, whichever is greater, and at least once for each sample matrix analyzed. 

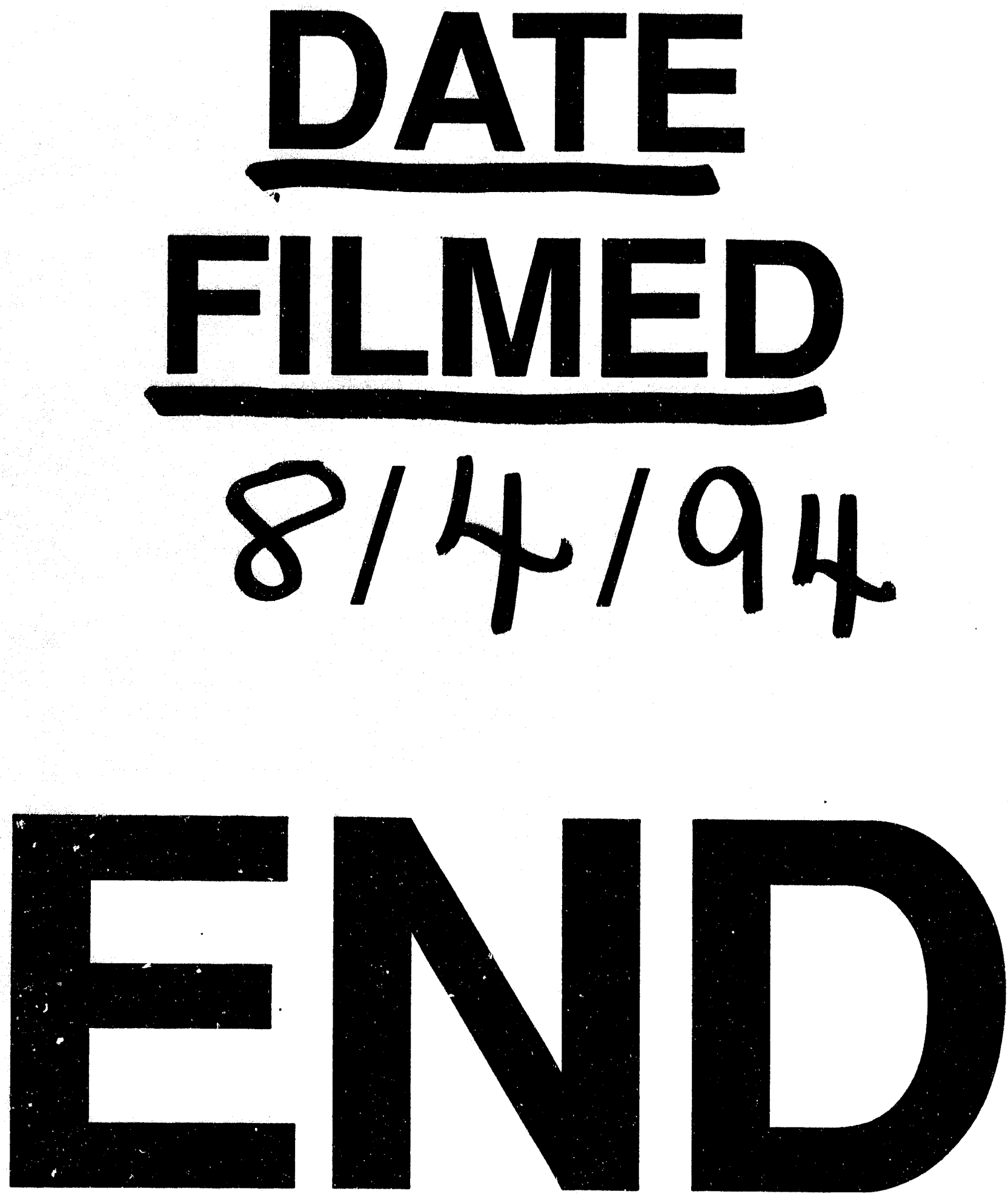
